\title{
Trainee Teachers Level of Willingness for Inclusive Education
}

\author{
Nancy Anthony, Mohd Hanafi Mohd Yasin \\ Universiti Kebangsaan Malaysia, Malaysia. \\ Email: nba99_2000@yahoo.com
}

\begin{abstract}
Every student at the Teacher Education Institute (IPG) has now been given an inclusive education course so they know about its implementation at school. Therefore, this research looks at how far the willingness of new teachers to be placed in schools with inclusive education. It was conducted in IPG in Sabah which involved 50 trainees from 5 different courses and took the Inclusive Education subject. It is a survey of quantitative reviews and uses questionnaires for data collection. The data were analyzed using Statistical Packages for the Social Science (SPSS) to see the frequencies, percentage and mean descriptive analysis. Besides, five trainee teachers from five different courses were interviewed to identify barriers that may interfere with the trainee teachers' willingness for inclusive education. The results showed that $86 \%$ of the trainee teachers are ready to accept special need students without prejudice and $84 \%$ are willing to approach and recognize special needs students in their classroom. The findings also showed that there was no significant difference in the readiness of the IPG trainee in the implementation of inclusive education based on gender namely $\mathrm{t}=-0.270$ with $\mathrm{P}=0.811$ greater than 0.05 $(\mathrm{P}<0.05)$. The trainee teachers should be able to meet the needs of students with disabilities in school. The success of inclusive education rests on teacher preparation gearing towards inclusive education. However, continuous guidance is essential to help produce qualified teachers, especially in understanding the underlying philosophy of inclusive education.
\end{abstract}

Keywords: Trainee Teachers of IPG, Inclusive Education, Willingness

\section{INTRODUCTION}

The demands on schools and teachers are becoming more complex as society now expects schools to deal effectively with different student background to promote tolerance and social cohesion, to respond effectively to special need students, to use new technologies and to keep pace with rapidly developing fields of knowledge and approaches to student assessment. Teachers, therefore, need confidence in their ability, knowledge and skills in inclusive education to meet the challenges that they will encounter in the present school climate. Hence, every student at the Teacher Education Institute (IPG) in Malaysia has now been given an inclusive education course so they will know about its implementation at school. Changes in education and in society place new demands on the teaching profession that require teachers not only to acquire new knowledge and skills but also to develop them continuously. IPG trainees need to possess pedagogical skills as well as specialist knowledge to their subjects, have sufficient incentives throughout their careers to review their learning needs and to acquire new knowledge, skills and competence, be able to teach key competences and to teach effectively in heterogeneous classes, engage in reflective practice research and also be autonomous learners in their own long professional career development. Inclusive education course is seen as an absolute main factor which directly relates and contributes to the process of producing and training teachers so that they can be wellequipped and professionally qualified to competently teach all students, both with and without special needs in practice.

According to the Incheon Declaration (United Nations Educational, Scientific and Cultural Organization) Morrissey (2012) it is clearly stated that there must be an assurance for all teachers to be welltrained and sufficiently recruited to possess professional qualifications, have their own empowerment and motivation and receive support under the systems which are well-supplied, productively governed and efficient so they are well-prepared and fully-equipped with sufficient knowledge and skills to deliver good quality education and enhance the learning outcomes of all students. This partial statement is a result of a new vision of education for all for the next era towards 2030, which will concentrate on ensuring good quality education that is not inequitable, yet inclusive and promoting life-long learning chances for all. The purpose of this study was to look at how far the willingness of new teachers to be placed in school on inclusive education. 


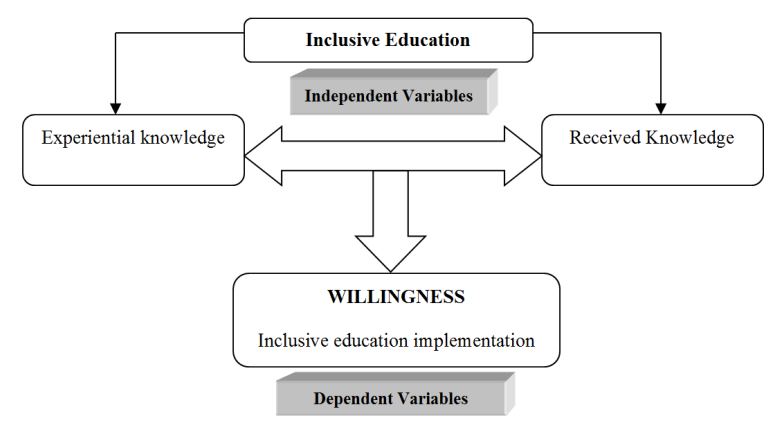

Figure 1. Wallace Reflective Theory

Table 1. The level of willingness of IPG trainee teachers

\begin{tabular}{ll}
\hline Mean Score & Interpretation \\
\hline $1.00-2.33$ & Low \\
$2.34-3.66$ & Moderate \\
$3.67-5.00$ & High \\
\hline
\end{tabular}

The purposes of this study are: (1)To explore trainee teachers' willingness towards inclusive education; (2) To identify trainee teachers 'willingness towards the implementation of inclusive education based on gender; (3) To identify barriers that may interfere with trainee teachers' willingness for inclusive education.

The theoretical framework of this study is based on Wallace Reflective Theory, Wallace and Bau (1991) as in figure 1 which shows that there is an association between the knowledge based on the existing experience of the teacher and the knowledge received through training because the teacher will relate that the received knowledge and experiential knowledge are two important sources of knowledge in professional practice. According to Wallace, it is interdependent with each other to enable teachers to be more willing to carry out their professional duties, especially in the preparation of Inclusive Education at primary level.

\section{METHOD}

This study was descriptive and was carried out using questionnaires adapted from Monahan, Marino and Miller (2006), and was modified to answer the research questions. The questionnaire was aimed to obtain information regarding the willingness of IPG trainee teachers in conducting inclusive education. Each respondent's response was collected and consolidated to be analyzed by likert method. The set of completed questionnaires was submitted to special education lecturers to obtain the expertise of the expert so that the content of the questionnaire is in line with the objectives and questions of the study. To determine the reliability of the instrument, the researcher conducted a pilot study on 10 trainee teachers in the Kota Kinabalu district. The reliability value for every aspect tested had high reliability of 0.92 to 0.96 and this value was accepted because of its high reliability of more than 0.05 . In this research, researchers have chosen IPG trainee teachers from various courses who took inclusive education subject. A total of 50 respondents have answered the questionnaires set.

Part A: Background of trainees - Respondents are required to complete information, options and have practicum training. Part B: The Likert Scale Questionnaire item was used as it can give a more accurate picture of respondents' responses. All respondents' answers were analyzed using SPSS software while the method used was mean comparison and descriptive analysis. In analyzing the data and looking at the level of willingness of IPG trainee teachers in the implementation of inclusive education, the scores were divided into three levels, namely low, medium and high. The mean value was based on Ahmad (2002) and is interpreted in Table 1.

Besides that, five trainee teachers from five difference courses were interview. An interview guide, consisting of 4 open-ended questions with probes was used to gather information from each trainee.

\section{FINDINGS AND DISCUSSION}

\section{Findings}

This section deals with the demographic of the study as well as the willingness of IPG trainers to the implementation of inclusive education. The following are the demographic information of the respondents involved in the study.

A total of 50 respondents responded to the questions. $15(35 \%)$ respondents are male and 35 $(65 \%)$ are female. 12 (24\%) from the Special Education course, 12 (24\%) from Islamic Religious Education course, $10(20 \%)$ from Science course, 8 (16\%) from Kadazandusun Language course, and 8 (16\%) from Malay Language course . 
Trainee teachers' willingness towards inclusive education

Table 2. The willingness level of the IPG Trainer on Implementation of Inclusive Education

\begin{tabular}{|c|c|c|c|c|c|c|c|c|}
\hline No. & Statement & $\begin{array}{l}\text { Strongly } \\
\text { Disagree }\end{array}$ & Disagree & $\begin{array}{c}\text { Less } \\
\text { Agree } \\
\end{array}$ & Agree & $\begin{array}{l}\text { Very } \\
\text { Agree } \\
\end{array}$ & Mean & $\begin{array}{c}\text { Interpreta- } \\
\text { tion }\end{array}$ \\
\hline 1 & $\begin{array}{l}\text { I understand the concept of } \\
\text { inclusive education }\end{array}$ & $\begin{array}{c}3 \\
(6 \%)\end{array}$ & $\begin{array}{c}1 \\
(2 \%)\end{array}$ & $\begin{array}{c}19 \\
(38 \%)\end{array}$ & $\begin{array}{c}2 \\
(4 \%)\end{array}$ & $\begin{array}{c}25 \\
(50 \%)\end{array}$ & 3.48 & Moderate \\
\hline 2 & $\begin{array}{l}\text { I am willing to meet the } \\
\text { needs of special needs } \\
\text { students to produce quality } \\
\text { learning. }\end{array}$ & $\begin{array}{c}2 \\
(4 \%)\end{array}$ & $\begin{array}{c}1 \\
(2 \%)\end{array}$ & $\begin{array}{c}0 \\
(0 \%)\end{array}$ & $\begin{array}{c}34 \\
(68 \%)\end{array}$ & $\begin{array}{c}13 \\
(26 \%)\end{array}$ & 3.60 & Moderate \\
\hline 3 & $\begin{array}{l}\text { I am willing to make the } \\
\text { reforms in the classroom for } \\
\text { the needs of students with } \\
\text { special needs. }\end{array}$ & $\begin{array}{c}1 \\
(2 \%)\end{array}$ & $\begin{array}{c}3 \\
(6 \%)\end{array}$ & $\begin{array}{c}16 \\
(32 \%)\end{array}$ & $\begin{array}{c}25 \\
(50 \%)\end{array}$ & $\begin{array}{c}5 \\
(10 \%)\end{array}$ & 3.52 & Moderate \\
\hline 4 & $\begin{array}{l}\text { I am willing to talk with a } \\
\text { special education teacher } \\
\text { to discuss about special } \\
\text { education students who are } \\
\text { in an inclusive class. }\end{array}$ & $\begin{array}{c}2 \\
(4 \%)\end{array}$ & $\begin{array}{c}3 \\
(6 \%)\end{array}$ & $\begin{array}{c}5 \\
(10 \%)\end{array}$ & $\begin{array}{c}35 \\
(70 \%)\end{array}$ & $\begin{array}{c}5 \\
(10 \%)\end{array}$ & 3.72 & High \\
\hline 5 & $\begin{array}{l}\text { I am willing to approach and } \\
\text { recognize special education } \\
\text { students who are inclusive } \\
\text { in my class. }\end{array}$ & $\begin{array}{c}1 \\
(2 \%)\end{array}$ & $\begin{array}{c}2 \\
(4 \%)\end{array}$ & $\begin{array}{c}5 \\
(10 \%)\end{array}$ & $\begin{array}{c}38 \\
(76 \%)\end{array}$ & $\begin{array}{c}4 \\
(8 \%)\end{array}$ & 3.78 & High \\
\hline 6 & $\begin{array}{l}\text { I am willing to take courses } \\
\text { to improve understanding } \\
\text { and skills in an inclusive } \\
\text { class. }\end{array}$ & $\begin{array}{c}2 \\
(4 \%)\end{array}$ & $\begin{array}{c}5 \\
(10 \%)\end{array}$ & $\begin{array}{c}14 \\
(28 \%)\end{array}$ & $\begin{array}{c}25 \\
(50 \%)\end{array}$ & $\begin{array}{c}4 \\
(8 \%)\end{array}$ & 3.40 & Moderate \\
\hline 7 & $\begin{array}{l}\text { I am willing to give } \\
\text { full attention to special } \\
\text { education students in my } \\
\text { class. }\end{array}$ & $\begin{array}{c}2 \\
(4 \%)\end{array}$ & $\begin{array}{c}5 \\
(10 \%)\end{array}$ & $\begin{array}{c}4 \\
(8 \%)\end{array}$ & $\begin{array}{c}35 \\
(70 \%)\end{array}$ & $\begin{array}{c}4 \\
(8 \%)\end{array}$ & 3.62 & Moderate \\
\hline 8 & $\begin{array}{l}\text { I am ready to accept special } \\
\text { needs students without } \\
\text { prejudice to them. }\end{array}$ & $\begin{array}{c}1 \\
(2 \%)\end{array}$ & $\begin{array}{c}1 \\
(2 \%)\end{array}$ & $\begin{array}{c}5 \\
(10 \%)\end{array}$ & $\begin{array}{c}38 \\
(76 \%)\end{array}$ & $\begin{array}{c}5 \\
(10 \%)\end{array}$ & 3.84 & High \\
\hline 9 & $\begin{array}{l}\text { I think that teaching } \\
\text { special needs students in } \\
\text { an inclusive class brings } \\
\text { problems in teaching and } \\
\text { learning sessions. }\end{array}$ & $\begin{array}{c}24 \\
(48 \%)\end{array}$ & $\begin{array}{c}13 \\
(26 \%)\end{array}$ & $\begin{array}{c}4 \\
(8 \%)\end{array}$ & $\begin{array}{c}5 \\
(10 \%)\end{array}$ & $\begin{array}{c}4 \\
(8 \%)\end{array}$ & 3.16 & Moderate \\
\hline 10 & $\begin{array}{l}\text { I am willing to innovate } \\
\text { in my teaching to attract } \\
\text { students to study in an } \\
\text { inclusive class. } \\
\text { Total }\end{array}$ & $\begin{array}{c}4 \\
(8 \%)\end{array}$ & $\begin{array}{c}3 \\
(6 \%)\end{array}$ & $\begin{array}{c}4 \\
(8 \%)\end{array}$ & $\begin{array}{c}35 \\
(70 \%)\end{array}$ & $\begin{array}{c}4 \\
(8 \%)\end{array}$ & 3.62 & Moderate \\
\hline
\end{tabular}

$n=50$

Table 2 shows that every item that has the highest mean is that trainee teachers are ready to accept special needs students without prejudice to them $($ mean $=3.84)$ remained at a high level. In terms of frequencies and percentages, it indicated a total of $38(76 \%)$ respondents expressed agree, a total of $5(10 \%)$ stated very agree, as much as $5(10 \%)$ stated less agree, 1 (2\%) disagree and $1(2 \%)$ stated strongly disagree. Items that have the lowest mean is trainee teachers think that teaching special needs students in an inclusive class brings problems in teaching and learning sessions (mean = 3.16 ) at a moderate level in terms of frequencies and percentage indicate a total of $4(8 \%)$ stated very agree, $5(10 \%)$ agree and a total of $4(8 \%)$ expressed less agree. $13(26 \%)$ respondents stated disagree and 24 (48\%) strongly disagree that teaching special needs students brings problems in the teaching learning sessions. 
Table 3. T-Test Analysis: The mean difference in the level of IPG trainee teachers willingness towards the implementation of gender-based inclusive education

\begin{tabular}{lcccccc}
\hline Gender & $\mathbf{N}$ & Mean & SD & $\boldsymbol{d} \boldsymbol{f}$ & $\boldsymbol{t}$ & $\boldsymbol{p}$ \\
\hline Male & 15 & 3.54 & 0.538 & 48 & -0.270 & 0.81 \\
Female & 35 & 3.58 & 0.438 & & -0.248 & \\
Total & 50 & & & & & \\
Sig- & & & & & & \\
nificant & & & & & \\
Level $<$ & & & & & \\
0.05 & & & & & \\
\hline Ho $_{0}$ There is no significant difference in the mean \\
of trainee teacher willingness based on gender.
\end{tabular}

To answer the second objectives of this study, the t-test was used to see the differences in the level of preparedness of IPG trainee teachers towards the implementation of inclusive education. The test results are as in table 3 .

The results of the analysis in table 3 show that there is no significant difference in the mean of readiness level of the IPG trainee teachers based on gender towards the implementation of inclusive education. The value of $t=-0.270$ with $\mathrm{p}=0.811$ is greater than $0.05(\mathrm{P}<0.05)$. Hence the null hypothesis is accepted. This shows no significant difference in the willingness of IPG trainee teachers in the implementation of genderbased inclusive education. The findings of this research also contradict to the research conducted by Al-Zyoudi (2006) which found that female teachers were more positive and prepared for the implementation of inclusive education than male teachers.

To answer the third objective, the analysis of the interview is presented as found that Respondents of the research indicated that they lack skills required for inclusive classroom setting. Whenasked about the availability of resource materials in the inclusive education course one of the participants stated that there are differences among courses about the available equipment of teaching students with disabilities. The interview also revealed the sentiments shared by respondents.

\section{Discussion}

From the results of the above findings, it is found that these trainee teachers are very welcome to the opportunity to teach in an inclusive setting. Similar result was found in a study conducted by Mergler (2017) where preservice teachers showed a willingnes to support students with diverse background. These teachers also took a service-learning program to enhance their knowledge regarding inlcusive education.

The effectivenes of an inclusive education is affected not only by teachers' knowledge but also their attitudes. This argument is in line with the result of the research by Dapudong (2014). It is also suported by Sharma et al. (2015) who believe that teachers' attitudes also determines the success of the implementation of inclusive education. Costello, and Boyle (2013) noted positive attitudes towards inclusive education in pre-service students who enrolled in post-graduate program.

However, the implementation of inclusive education will not run accordingly without the support from the government. The legislation will keep the commitment of schools conducting inclusive education, and the policy will help to give guidance for all stakeholdres (Sharma et al., 2015; Hay et al., 2001).

\section{CONCLUSION}

Based on the results of the research, an inclusive education program to prepare IPG trainees should be improved to meet the need to produce quality teachers. Dissemination of the latest information, collaborating with other agency such as schools with inclusive programs is crucial to prepare them for inclusive education in the future. Therefore, continuous support is essential to build high self-esteem among the trainee teachers. It was further asserted that teachers who previously took special education modules or programs appeared to respond towards inclusion of special needs children in a positive way. Overall, this study has reviewed the willingness of IPG trainee teachers to the implementation of inclusive education. Continuous efforts are necessary to ensure the implementation of inclusive education can be successfully carried out.

\section{REFERENCES}

Ahmad, J. (2002). Pemupukan budaya penyelidikan di kalangan guru di sekolah: Satu penilaian [Inculcation of research culture among teachers in schools: An evaluation]. The National University of Malaysia.

Al-Zyoudi, M. (2006). Teachers' Attitudes towards Inclusive Education in Jordanian Schools. International Journal of Special Education, 21(2), 55-62.

Costello, S., \& Boyle, C. (2013). Pre-service secondary teachers' attitudes towards inclusive education. Australian Journal of Teacher Education, 38(4), 8. 
Dapudong, R. C. (2014). Teachers' knowledge and attitude towards inclusive education: Basis for an enhanced professional development program. International Journal of Learning \& Development, $4(4), 1-24$.

Hay, J. F., Smit, J., \& Paulsen, M. (2001). Teacher preparedness for inclusive education. South African Journal of Education, 21(4), 213-218.

Mergler, A., Carrington, S. B., Kimber, M. P., Bland, D., \& Boman, P. (2017). Exploring the Value of Service-Learning on Preservice Teachers. Australian Journal of Teacher Education, 42(6), 69-80.
Monahan, R. G., Marino, S. B., \& Miller, R. (1996). Teacher attitudes toward inclusion: Implications for teacher education in schools 2000. Education, $117(2), 316-321$.

Morrissey, F. (2012). The United Nations Convention on the Rights of Persons with Disabilities: a new approach to decision-making in mental health law. European Journal of Health Law, 19(5), 423-440.

Sharma, U., Simi, J., \& Forlin, C. (2015). Preparedness of Pre-Service Teachers for Inclusive Education in the Solomon Islands. Australian Journal of Teacher Education, 40(5), 103-116.

Wallace, M. J., \& Bau, T. H. (1991). Training foreign language teachers: A reflective approach. Cambridge University Press. 